\title{
GENERAL EQUILIBRIUM ECONOMICS
}


Also by Robert E. Kuenne

THE THEORY OF GENERAL ECONOMIC EQUILIBRIUM

THE ATTACK SUBMARINE: A Study in Strategy

THE POLARIS MISSILE STRIKE: A General Economic Systems Analysis

MONOPOLISTIC COMPETITION THEORY: Studies in Impact (editor)

* MICROECONOMIC THEORY OF THE MARKET MECHANISM: A General

Equilibrium Approach

EUGEN von BÖHM-BAWERK

RIVALROUS CONSONANCE: A Theory of General Oligopolistic Equilibrium WARRANTIES IN WEAPON SYSTEMS PROCUREMENT

(with $P$. H. Richanbach, F. Ridell and R. Kaganoff)

MICROECONOMIC THEORY: Theoretical and Applied, Vols I, II, and III (editor)

* DYNAMICS AND CONFLICT IN REGIONAL STRUCTURAL CHANGE (co-editor with Manas Chatterii)

* NEW FRONTIERS IN REGIONAL SCIENCE (co-editor with Manas Chatterii) THE ECONOMICS OF OLIGOPOLISTIC COMPETITION: Price and Non-Price Rivalry

* Also published by Macmillan 


\section{General Equilibrium Economics}

\section{Space, Time and Money}

Robert E. Kuenne

Professor of Economics

Princeton University

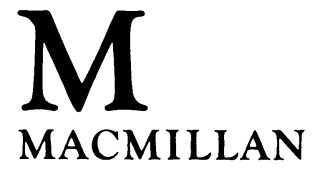


(C) Robert E. Kuenne 1992

Softcover reprint of the hardcover 1st edition 1992

All rights reserved. No reproduction, copy or transmission of this publication may be made without written permission.

No paragraph of this publication may be reproduced, copied or transmitted save with written permission or in accordance with the provisions of the Copyright, Designs and Patents Act 1988, or under the terms of any licence permitting limited copying issued by the Copyright Licensing Agency, 90 Tottenham Court Road, London W1P 9HE.

Any person who does any unauthorized act in relation to this publication may be liable to criminal prosecution and civil claims for damages.

First published 1992 by

THE MACMILLAN PRESS LTD

Houndmills, Basingstoke, Hampshire RG21 2XS

and London

Companies and representatives

throughout the world

ISBN 978-1-349-12754-2 ISBN 978-1-349-12752-8 (eBook)

DOI 10.1007/978-1-349-12752-8

A catalogue record for this book is available from the British Library 
For my children

\section{Christopher Brian Kuenne \\ Carolyn Kuenne Jeppsen}

with loving memories of their childhoods, great pride in their adulthoods and thankful joy in their companionship 


\section{Contents}

Preface ix

Acknowledgements $\quad$ xi

Introduction $\quad 1$

PART I GENERAL EQUILIBRIUM THEORY: THE ECONOMICS OF INTERDEPENDENCE

1 Walras, Leontief and the Interdependence of Economic Activities

2 The Architectonics of Léon Walras

3 On Hicks's Concept of Perfect Stability in Multiple Exchange

4 The Impact of Steel upon the Greater

New York-Philadelphia Industrial Region

5 Employment Impacts of Achieving Automobile Efficiency Standards in the United States

6 General Equilibrium Analysis: Its Meaning, Purposes and Limitations

7 Oligopoly under Rivalrous Consonance:

An Exploration of Phantom Objective Functions and some Algorithmic Considerations

8 The Rivalrous Consonance Framework for Oligopoly Analysis

\section{PART II SPATIAL INTERDEPENDENCE}

9 An Efficient Algorithm for the Numerical Solution of the Generalized Weber Problem in Spatial Economics 
10 Exact and Approximate Solutions to the Multisource Weber Problem

11 Approximate Solutions to a Dynamic Combinatorial Problem in Space

12 Exact and Approximate Solution of Constrained Dynamic Combinatorial Problems in Space

13 Economic Decision-Making in a Poisson Demand Space 306

PART III OF TIME: AUSTRIAN CAPITAL THEORY

14 Eugen von Böhm-Bawerk

15 The Stationary State and the Technological Superiority of Present Goods

16 The Technological Superiority of Present Goods

\section{PART IV MONEY IN A GENERAL EQUILIBRIUM FRAMEWORK}

17 On the Existence and Role of Money in a Stationary System

18 Patinkin on Neo-Classical Monetary Theory:

A Critique in Walrasian Specifics

19 Keynes's Identity, Ricardian Virtue and the Partial Dichotomy

20 The Walrasian Theory of Money: An Interpretation and a Reconstruction

21 Say's Law and Walras's Law Once More: Comment

22 Money, Capital and Interest in Intertemporal General Equilibrium Theory 


\section{Preface}

General equilibrium economics has made great strides since Hicks and Samuelson began to move Anglo-American economic theory beyond the confines of Marshallian statics into the wider vistas of the Walrasian-Paretian legacy. In the 1950s Arrow and Debreu applied the techniques of real analysis, set theory and topology within a game-theoretic context to investigate the necessary and sufficient conditions for the existence of a general equilibrium. Lange and Patinkin initiated an examination into the integration of monetary and real sectors in such systems. During the same period Leontief's input-output derivative began to be applied directly to realistic problems and to be embedded in more ambitious econometric models to the same end. And during the 1960s and 1970s operational general equilibrium frameworks were developed with greater sophistication for applied work.

But much labor remains to be done to improve the field. Some progress has been made in moving general equilibrium theory away from its pure competition moorings, but that task has just begun. Welfare economics - which general equilibrium theory must motivate - must be reworked to incorporate imperfect competition. Uncertainty and imperfect information must be intruded into the theory, and space still beckons as a largely excluded dimension. And better methods of teaching general equilibrium systems analysis and instilling its 'vision' of economic reality would be welcomed.

In the present volume I have selected twenty-two of my papers in the field that are grouped into four areas of interest. The first treats the general theoretical and empirical problems and successes in general equilibrium economics, explaining its general structure and uses, and culminating in my attempt to build a model of general oligopolistic equilibrium. A second area concerns some investigations into spatial interdependence, including development of exact and approximate solution algorithms as well as investigation of a Poisson process in space. The third topic is concerned with the attempt of Austrian theorists, especially Böhm-Bawerk, to build a general equilibrium approach to capital and interest theory. And the last area concerns the integration of money and real sectors in Walrasian and Keynesian models, as well as the conditions for the 
existence of money in a stationary state and the role of money in an intertemporal general system.

The topics are, I believe, enduring themes in general equilibrium analysis, embracing concerns about the foundations of economic theory, and therefore likely to remain of importance to theorists. They will continue to be researched and will stimulate new and better insights into the market economy, I am sure. Today's young economist, much better equipped with the mathematical apparatus to probe into variate interdependence than were most economists of my generation, has a great potential for improvement of the understanding of the system. But there is a danger that methodology will become an end rather than a means, so that much talent will be wasted in seeking ingenious solutions to questions that are amenable to attack by such techniques but which have no issue of discernible relevance to the phenomena of this earth. If this eventuates, general equilibrium economics will be cordoned off from the body of economic analysis by a wall of antagonistic - and much-merited disinterest. Care must be taken to choose realistic problems for research and to make the results of that research accessible to the economic practitioner.

My hope is that the present volume will encourage efforts in these directions. I have been indebted over my career to a large number of individuals who inspired my interest in economics in general and economic theory in particular. Professor Werner Hochwald of Washington University in St. Louis was especially influential in these respects. Professors Edward H. Chamberlin, William Fellner, Walter Isard, Guy Orcutt and Arthur Smithies at Harvard were exceptionally inspiring.

I am also grateful for the financial support of the Ford Foundation, Rockefeller Foundation, National Endowment for the Humanities, the National Science Foundation and the Fulbright Commission during various periods of my research. And, finally, I have enjoyed the gracious hospitality of the University of Vienna during my stay in Austria, and am especially indebted to Professors E. Streissler and E. Weissel of the Institut für Wirtschaftswissenschaften at that institution for their support and encouragement.

ROBERT E. KUENNE 


\section{Acknowledgements}

The author and publishers wish to thank the following for permission to reproduce the chapters indicated.

John Wiley \& Sons, publishers of the Quarterly Journal of Economics, for permission to reprint Chapters 1, 3, 15 and 21.

Helbing \& Lichtenhahn Verlag AG, Basel, and Frankfurt/M, publishers of Kyklos, for permission to reprint Chapter 2.

Elsevier Science Publishers, publishers of A. Andersson, W. Isard and T. Puu (eds), Regional and Industrial Development Theories, Models and Empirical Evidence; Robert E. Kuenne, Rivalrous Consonance: $A$ Theory of General Oligopolistic Equilibrium; Review of Economics and Statistics; and Mathematical Programming, for permission to reprint Chapters 4, 8, 10 and 13.

Chapman \& Hall, publishers of Applied Economics, for permission to publish Chapter 5.

Princeton University Press, publishers of Robert E. Kuenne, The Theory of General Economic Equilibrium, for permission to reprint Chapter 6.

Editrice Cedam, publishers of Rivista Internazionale di Scienze Economiche e Commerciali, for permission to reprint Chapter 7.

The Journal of Regional Science for permission to reprint Chapters 9, 11 and 12.

Columbia University Press, publishers of Robert E. Kuenne, Eugen von Böhm-Bawerk, for permission to reprint Chapter 14.

Springer-Verlag Wien, publishers of Zeitschrift für Nationalökonomie, for permission to reprint Chapter 16. 
xii Acknowledgements

The Southern Economic Journal for permission to reprint Chapters 17 and 18.

The Canadian Journal of Economics for permission to reprint Chapter 19.

Metroeconomica for permission to reprint Chapter 20.

Librairie Droz SA, Geneva, publishers of Economie Appliquée, for permission to reprint Chapter 22.

Note: the reprinted material appears as in the original publications except that minor alterations have been made to the style and presentation for the purpose of publishing this collection of readings in book form. 